\title{
Biofilm Formation by Uropathogens and Their Susceptibility Towards Antimicrobial Therapy
}

\author{
Mahesh Prakash Bhatta', Asmita Sapkota², Pushpa Subedi, Sunita Baniya Chhetri4, \\ Dhaka Raj Pant ${ }^{3}$, Mukund Joshi $^{5}$, Santosh Pandit ${ }^{6}$ and Dipendra Raj Pandeya ${ }^{7}$
}

${ }^{1}$ Department of Laboratory, Malakheti Hospital, Ministry of Health and Population, Attariya, Nepal 2Department of Laboratory, Mid-Western Regional Hospital, Ministry of Health and Population, Surkhet, Nepal ${ }^{3}$ Department of Laboratory Science, School of Health and Allied Sciences, Pokhara University, Nepal ${ }^{4}$ Brisbane campus, Torrens University, Brisbane, Australia

${ }^{5}$ Department of Laboratory, Seti Zonal Hospital, Ministry of Health and Population, Dhangadhi, Nepal ${ }^{6}$ Department of Biology and Biological Engineering, Chalmers University of Technology, Gothenburg, Sweden ${ }^{7}$ Department of Biochemistry and Genetics, Medical University of Americas, Saint Kitts and Nevis, West Indies

\begin{abstract}
Introduction: Urinary tract infection (UTI) is the most common health care associated infection caused by various pathogenic bacteria. Biofilms are communities of bacteria that are held together by exopolymeric substances that protect against the antimicrobial therapy and other environmental assaults. The aim of this study was to estimate the prevalence of biofilm forming bacteria in Nepalese population and to study the emergence of antimicrobial resistance among biofilm producing bacteria in comparison to non-biofilm producing bacteria.

Methods: A total of 785 clean-caught-mid-stream urine samples were collected. After isolation and identification of uropathogens, they were further processed for detection of biofilm formation by two methods (Congo Red Agar method and Tissue Culture Plate method) as well as for antibiotic sensitivity test.

Results: Out of total collected samples, $12.74 \%$ were found to be associated with UTI, among them $67 \%$ were Escherichia coli, 10\% were Klebsiella spp, 7\% were Pseudomonas spp, 6\% were Staphyloccous aureus, 4\% were Enterobacter spp, 3\% were Proteus spp, 2\% were Citrobacter spp and remaining 1\% was Staphylococcus saprophyticus. Among isolated organisms, the ratio of bioflim positive organism to bioflim negative organism was found to be 9:11. Nitrofurantoin, Tobramycin, Chloramphenicol, Amikacin and Imipenem were found to be significantly more sensitive in biofilm negative bacteria as compared to biofilm positive bacteria with $p$ values of $0.000,0.001,0.000,0.000$ and 0.001 .

Conclusions: The prevalence rate of multidrug resistance in bacterial uropathogens was higher in biofilm producers as compared to non-biofilm producers. Biofilm forming characteristic of bacteria make them more resistant to antibiotics.
\end{abstract}

Key words: antibiotic resistance; biofilm; urinary tract infection; uropathogens

Correspondence: Mahesh Prakash Bhatta. Department of Laboratory, Malakheti Hospital, Ministry of Health and Population, Attariya, Nepal. E-mail:bhattamahesh04@gmail.com

DOI: $10.3126 /$ mjsbh.v18i1.20189

Submitted on: 2018-06-07

Accepted on: 2018-12-17

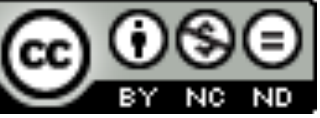

This work is licensed under creative common license:

http://creativecommons.org/licenses/by-nc-nd/4.0/ C MJSBH 2018 


\section{INTRODUCTION}

Urinary Tract Infections (UTIs) are very challenging infectious diseases that are frequently encountered in clinical practices. ${ }^{1,2}$ Basically the infection caused by various pathogens in urinary tract is defined as a UTI. ${ }^{1}$ UTIs are most common infections with its diverse clinical syndromes, affecting humans throughout their life span accounting for an estimated $25-40 \%$ of the nosocomial infections. 1,3 The continuous use of indwelling devices such as catheters and urethral stents or sphincters and long duration of catheterisation significantly increases the risk of developing UTI.2,4 Although E. coli is considered as a main etiological agent for UTI, P. mirabilis, $P$. aeruginosa, $K$. pneumonia and $S$. faecalis are also isolated frequently from urine samples of UTI patients and also considered as causative agents. ${ }^{5}$ The majority of acute UTI are uncomplicated and can be easily cured by antibiotics, however, frequent use of antibiotics increase the risk of antimicrobial resistance. ${ }^{6}$ Furthermore, highly dense bacterial community develops on biofilm and helps in protecting against the antimicrobial exposure which facilitates the development of antimicrobial resistance. ${ }^{7}$

Biofilm development starts with the adhesion of free floating bacteria on any kind of surfaces. ${ }^{8}$ Initial adhesion might be reversible and can be detached easily due to the environmental alteration. ${ }^{7}$ The growth of adhered bacterial population further starts to proliferate and produce exopolysaccharides and proteins, collectively called an exopolymeric substance (EPS). ${ }^{9}$ The EPS matrix in the biofilm not only provide protection against the antimicrobial agents but also preserve nutrients. ${ }^{10}$ The process of biofilm formation and the impact on the development and clinical course of infectious diseases is still lacking beyond our conscience. ${ }^{11}$ Biofilms have major medical significance since they show high resistance towards various antimicrobial agents by restricting the diffusion of substances and binding of antimicrobials. They also provide protection against large molecules such as antimicrobial proteins lysozyme and complement. ${ }^{12}$ Additionally, the proximity of cells within a biofilm can facilitate plasmid exchange, that enhances the spreading of antimicrobial resistance. ${ }^{13}$ Bacteria communicate with each other by a phenomenon called quorum sensing in which production of chemotactic particles or pheromones occurs within a biofilm. ${ }^{14}$ The fact that biofilm bacteria are able to resist higher antibiotic concentration, about 1,000 fold than bacteria in suspension, has made it difficult in eradicating chronic infections associated with biofilm formation. ${ }^{15,16}$

The antibiotics that are given to UTI patients might only eradicate the planktonic bacteria but might not have similar efficiency towards the biofilm forming bacteria. In conventional laboratory testing methods, microorganisms that are apparently sensitive to antibiotics and antiseptics become fully resistant in the biofilm mode, in vivo. ${ }^{17}$ This treatment scenario in underdeveloped countries like Nepal increases the ability of resistance in biofilm environment which ultimately leads to re-infections and re-occurrence of UTI with further complications even after the completion of antibiotic course of treatment. The resulting limitations on the therapeutic options demand new measures for the management of infections caused by biofilm forming pathogens.

Despite having many patients with UTI caused by biofilm positive organism in Nepal, there are very limited studies done before. The aim of this study was to estimate the prevalence of biofilm forming bacteria in Nepalese population and to study the emergence of antimicrobial resistance among 
biofilm producing bacteria in comparison to nonbiofilm producing bacteria.

\section{METHODS}

It was a hospital based prospective experimental study conducted from $1^{\text {st }}$ September, 2014 to $28^{\text {th }}$ February, 2015. A total of 785 Patients (344 male and 441 female) were involved where Clean Catch Mid-Stream Urine (CCMSU) samples (at least $5 \mathrm{ml}$ ) were collected from patients that were suspected for UTI at Western Regional Hospital and Western Regional Laboratory, Pokhara, Nepal. Samples were transported to microbiology laboratory of Pokhara University in ice pack.

All the samples were processed within two hours of collection. Urine samples were aseptically inoculated onto Cysteine-, Lactose-, and Electrolyte-Deficient (CLED) media. Colony count of more than $10^{5} \mathrm{CFU} / \mathrm{ml}$ was considered significant and further processed for identification.

The biofilm formation ability of all isolated organisms was screened by using Congo Red Agar method (CRA) and further evaluated by Tissue Culture Plate method (TCP) ${ }^{18,19}$ and was incubated aerobically at $37^{\circ} \mathrm{C}$ for 24 hours in Congo red agar. Dry black crystalline colonies were considered as strong biofilm positive strains, darker colonies without dry and crystalline structure were considered as weak positive and the appearance of pink colonies were realised to be biofilm negative bacteria. The suspected biofilm forming strains were further evaluated by TCP method. ${ }^{20} 200 \mu 1$ of bacterial suspension was inoculated in flatbottomed 96 well clear polystyrene tissue culture treated microtiter plate with correspondence to 0.5 McFarland standard solution (with further 1:100 dilution). The contents of each well were decanted and each well was washed three times with $300 \mu 1$ of sterile saline after 24 hours incubation at $37^{\circ} \mathrm{C}$. Further, biofilms were incubated at $60^{\circ} \mathrm{C}$ for 60 min in incubator. The attached bacteria were heatfixed by exposing them to hot air followed by the addition of $200 \mu \mathrm{l}$ safranine $(0.1 \%)$ stain to each well and incubated for 30 minutes. Excess stain was rinsed off by decantation, and the plates were washed. Finally, $150 \mu 1$ of $95 \%$ ethanol was added and incubated at $4^{\circ} \mathrm{C}$ for $30 \mathrm{~min}$, and the optical density (OD) of the solution was measured at 570 $\mathrm{nm}$ using an enzyme linked immunosorbent assay reader. The average OD values were calculated for all tested strains and negative controls and a cut-off value (ODc) was established. It is defined as a three standard deviations (SD) above the mean OD of the negative control:

For easier interpretation of the results, strains were divided into following categories ${ }^{16}$ :

- Non biofilm producer $=\mathrm{OD} \leq \mathrm{ODc}$

- Weak biofilm producer $=\mathrm{ODc}<\mathrm{OD} \leq 2 \times \mathrm{ODc}$,

- Moderate biofilm producer $=2 \times \mathrm{ODc}$ $<\mathrm{OD} \leq 4 \times \mathrm{ODc}$

- Strong biofilm producer $=4 \times \mathrm{ODc}<\mathrm{OD}$

Antibiotic sensitivity test was performed by Kirby Bauer disk diffusion method. ${ }^{21}$ According to the Clinical and Laboratory Standards Institute (CLSI) guidelines; sensitive, intermediate and resistance to each of the antibiotic discs were identified.

All the analysis of statistical data was done using SPSS V17.0 software. Mean and Standard Deviation is represented as Mean \pm S.D. p-value less than 0.05 was considered to be significant.

\section{RESULTS}

A total of 785 patients, 344 males (43.8\%) and 441 females $(56.2 \%)$ were included in this study out of which 100 were UTI patients. Out of 100 UTI positive cases, 72 were females and 28 were males. Among 100 isolated organisms a total of 45 organisms showed biofilm property represented in Fig 1. 


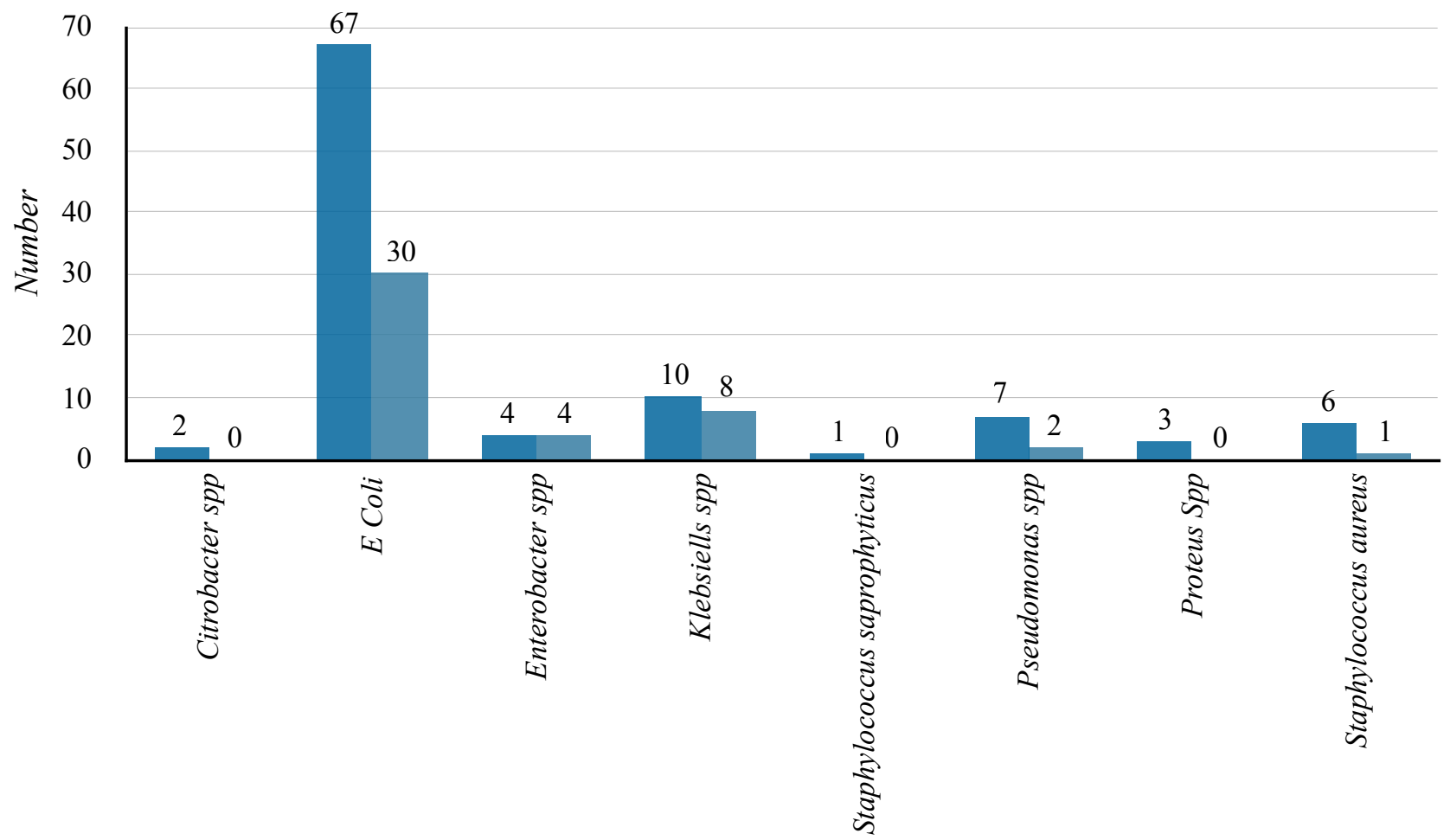

Isolated uropathogen

Fig 1. Isolated organisms in urine sample

Among the isolated organisms, 43 negative, 27 weak positive and 30 strong positive strains were detected by CRA method. Those 57 positive cases from CRA method were further processed for TCP method, which showed 12 negative, 28 weak positive, 12 moderately positive and five strong

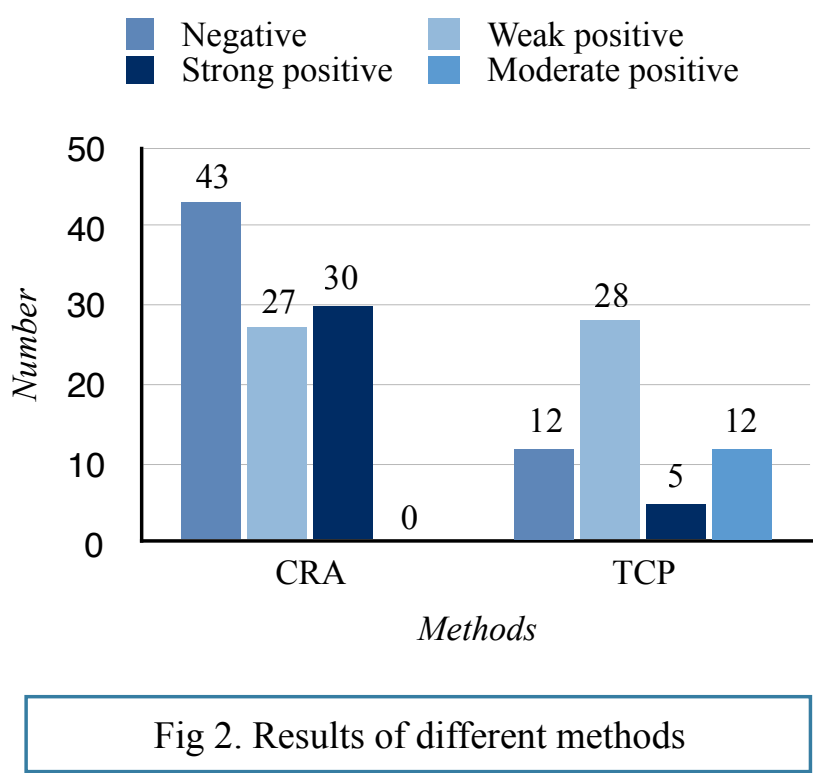

positive. In conclusion, 45 were found to be biofilm positive, and remaining 55 were biofilm negative as shown in fig 2. Number of isolated biofilm forming strains were cross analysed with age and gender of the patients and presented in Table 1 . Only 45 cases had shown biofilm positive i.e. 34 (47.22\% among female) cases from female and 11 (39.29\% among male) cases from male. Age group between 20-39

Table 1. Distribution of isolated organisms among different age group and gender

\begin{tabular}{|l|r|r|r|r|r|}
\hline Age & \multicolumn{2}{|c|}{ Male } & \multicolumn{2}{c|}{ Female } & Total \\
group & $\begin{array}{c}\text { Biofilm } \\
\text { positive }\end{array}$ & $\begin{array}{c}\text { Biofilm } \\
\text { negative }\end{array}$ & $\begin{array}{l}\text { Biofilm } \\
\text { positive }\end{array}$ & $\begin{array}{c}\text { Biofilm } \\
\text { negative }\end{array}$ \\
\hline $0-19$ & 3 & 3 & 2 & 8 & 16 \\
\hline $20-39$ & 3 & 4 & 21 & 16 & 44 \\
\hline $40-59$ & 1 & 3 & 3 & 7 & 14 \\
\hline$>59$ & 4 & 7 & 8 & 7 & 26 \\
\hline Total & 11 & 17 & 34 & 38 & 100 \\
\hline
\end{tabular}


Table 2. Antimicrobial susceptibility pattern among all isolated, biofilm positive and biofilm negative uropathogens

\begin{tabular}{|c|c|c|c|c|c|c|c|c|c|}
\hline \multirow[b]{2}{*}{ Antibiotics/mcg } & \multicolumn{3}{|c|}{ As a whole $(\%)$} & \multicolumn{3}{|c|}{$\begin{array}{l}\text { Biofilm positive } \\
\text { isolates }(\%)\end{array}$} & \multicolumn{3}{|c|}{$\begin{array}{l}\text { Biofilm negative } \\
\text { isolates }(\%)\end{array}$} \\
\hline & $\mathrm{R}$ & I & $\mathrm{S}$ & $\mathrm{R}$ & I & $\mathrm{S}$ & $\mathrm{R}$ & I & $\mathrm{S}$ \\
\hline Amikacin (AK)/30 & 15 & 6 & 79 & 20 & 11 & 69 & 11 & 2 & 87 \\
\hline Chloramphenicol (C)/30 & 10 & 7 & 83 & 11 & 9 & 80 & 9 & 6 & 85 \\
\hline Imipenem (IPM)/10 & 14 & 16 & 70 & 18 & 13 & 69 & 11 & 18 & 71 \\
\hline Tobramycin (TOB)/10 & 22 & 9 & 69 & 38 & 11 & 51 & 9 & 7 & 84 \\
\hline Nitrofurantoin (NIT)/300 & 28 & 13 & 59 & 37 & 11 & 52 & 20 & 15 & 65 \\
\hline Co-Trimoxazole $(\mathrm{COT}) / 25$ & 55 & 3 & 42 & 69 & 0 & 31 & 44 & 6 & 50 \\
\hline Ciprofloxacin (CIP)/5 & 54 & 12 & 34 & 62 & 7 & 31 & 47 & 16 & 37 \\
\hline Ceftriaxone $(\mathrm{CTX}) / 30$ & 61 & 17 & 22 & 76 & 13 & 11 & 49 & 20 & 31 \\
\hline Norfloxacin (NX)/10 & 60 & 7 & 33 & 69 & 4 & 27 & 53 & 9 & 38 \\
\hline Azithromycin (AZM)/15 & 75 & 14 & 11 & 78 & 13 & 9 & 73 & 15 & 12 \\
\hline Nalidixic Acid (NA)/30 & 85 & 5 & 10 & 84 & 9 & 7 & 86 & 2 & 12 \\
\hline Ampicillin (AMP)/10 & 100 & 0 & 0 & 100 & 0 & 0 & 100 & 0 & 0 \\
\hline Ceftazidime $(\mathrm{CAZ}) / 30$ & 100 & 0 & 0 & 100 & 0 & 0 & 100 & 0 & 0 \\
\hline Erythromycin (E)/15 & 97 & 3 & 0 & 96 & 4 & 0 & 98 & 2 & 0 \\
\hline
\end{tabular}

$R$, resistant; I, intermediate; $S$, sensitive

years had highest prevalence rate of both UTIs and biofilm positive cases i.e. seven UTIs with three $(6.67 \%)$ biofilm positive cases in males and 37 UTIs with 21 (46.67\%) biofilm positive cases in females. Age group of 40-59 years had lowest prevalence rate of both UTIs and biofilm positive cases i.e. 10 UTIs with three $(6.67 \%)$ biofilm positive case in female and four UTIs with one $(2.22 \%)$ biofilm positive cases in male.

Antimicrobial susceptibility pattern among all isolated biofilm positive and biofilm negative uropathogens were evaluated and presented in Table 2. Most sensitive drugs were Chloramphenicol (83\%), Amikacin (79\%), Imipenem (70\%), and Tobramycin (69\%) while most resistant drugs were Ampicillin (100\%), Ceftazidime (100\%), Erythromycin (97\%) and
Nalidixic Acid (85\%). Resistant number of antibiotics of biofilm positive uropathogens is higher than resistance number of biofilm negative bacteria (for example: in amikacin, 20 vs 11) whereas sensitive number of antibiotics of biofilm negative uropathogen is higher than sensitive number of biofilm positive uropathogens (for example; in amikacin, 87 vs 69).

Further, data analysis of biofilm positive and biofilm negative pathogens against their antibiotics inhibition zone is shown in Table 3. Nitrofurantoin, Tobramycin, Chloramphenicol, Amikacin and Imipenem were found to be significantly more sensitive in biofilm negative bacteria as compared to biofilm positive bacteria with $\mathrm{p}$ values of 0.000 , $0.001,0.000,0.000$, and 0.001 respectively. This significantly indicates that biofilm positive 
Table 3. Data analysis of biofilm positive and biofilm negative pathogens against their antibiotics inhibition zone

\begin{tabular}{|l|r|r|r|r|r|}
\hline Antibiotic & Biofilm positive & Biofilm negative & Mann-Whitney U & Z Value & p Value \\
\hline Nitrofurantoin & 24.19 & 42.6 & 275 & -3.705 & 0.000 \\
\hline Tobramycin & 27.2 & 44.07 & 356 & -3.25 & 0.001 \\
\hline Chloramphenical & 34.04 & 54.67 & 541.5 & -3.74 & 0.000 \\
\hline Amikacin & 29.13 & 56.18 & 366 & -5 & 0.000 \\
\hline Imipenum & 33.24 & 50.89 & 530.5 & -3.24 & 0.001 \\
\hline
\end{tabular}

uropathogens are relatively more resistant than biofilm negative uropathogens, which implies that biofilm producing properties of bacteria make them more resistant towards antibiotics. Relatively decreasing zone of inhibition of biofilm producing bacteria in comparison to non-biofilm producers indicates the flow of bacteria towards development of resistance.

Antimicrobial resistant pattern of antibiotics was evaluated on the basis of gender. The mean resistance percentage of male and female is $58.41 \%$ and $54.27 \%$ respectively. This indicates that the males are relatively more resistant than females (mean difference $=4.13 \%)(\mathrm{p}=0.000)$. The mean sensitive percentage of males and females are $33.67 \%$ and $37.69 \%$ respectively, which indicates that females are relatively more sensitive than males $($ mean difference $=4.02 \%)(p=0.000)$.

\section{DISCUSSION}

This study found prevalence rate of UTIs was $12.73 \%$ i.e. 100 out of total cases where male (28): female (72) are in the ratio of 1:2.57. Female cases were higher compared to male cases because of short and close proximity of anus to urethra, relatively high moisture and socio-economic concerns. ${ }^{22}$ A study done by Abdallah et al. also found male:female ratio of 1:1.94 which is correlated with our study. ${ }^{2}$ In our study, prevalence of UTIs was higher among 20-39 year age group (44\%) of total isolates. This was in conclusion with
Beyene et al.'s study in which $53.5 \%$ were in the age group between 19-39 years. ${ }^{23}$ John et al. also has reported that 21-40 yrs age group has high prevalence $(86.1 \%){ }^{24}$

Present study shows that, out of these 100 strains, the most frequently isolated pathogen was E.coli; i.e. $67 \%$ which was similar to the research carried out by Thapa et al. i.e $65.1 \% .{ }^{25}$ Baral et al. showed slightly higher prevalence $81.3 \%$ of E. coli followed by Citrobacter spp (5\%), Klebsiella spp (2.7\%), CoNS (2.7\%), Enterobacter spp (1.8), P. mirabilis (1.4\%), Pseudomonas spp $(0.9 \%)$ and other $(4.2 \%)$, these tests were conducted at Kathmandu Model Hospital. ${ }^{26}$ Similar findings were reported by Subramanian et al. i.e. E. coli (70\%), followed by Klebsiella spp (16\%), P. a eruginosa $(4 \%)$, Acinetobacter spp (2\%), coagulase negative Staphylococci $(6 \%)$ and Enterococci spp (2\%). ${ }^{27}$ Gram-negative aerobic rods accounted for $92 \%$ and gram-positive cocci account for the remaining $8 \%$ of the 100 significant isolates of the total pathogens. In Fig 1, the frequency and distribution of the different microorganisms is summarised. Similarly, AlAsoufi et al. showed Escherichia coli (48.2\%), P. aeruginosa $(7.8 \%), \mathrm{K}$. pneumoniae $(6.9 \%)$, E. faecalis $(6.03 \%)$, S. aureus $(5.2 \%)$, Acinetobacter baumannii $(0.9 \%)$, and Citrobacter spp. $(0.86 \%)$ in UTI patients were the most prevalent microorganisms. ${ }^{28}$ 
In this study, $45 \%$ were detected as biofilm positive by CRA (as screening) and TCP method (as confirmatory), which comes in accordance with the results presented by Mishra et al. i.e. nearly $46 \%$ of the isolates were found to be biofilm positive. ${ }^{29}$ Out of 300 isolates tested, the number of biofilm producers identified by TCP method was $45.6 \%$ according to the regional data from India. ${ }^{30}$ Hassan et al. ${ }^{20}$, Niveditha et al. ${ }^{31}$ and Bellifa et al. ${ }^{32}$ showed relatively higher i.e. $63.6 \%, 60 \%$, and $69 \%$ respectively, biofilm positive by TCP method. In our study, $47 \%$ of females (34 out of 72 female) and $39 \%$ of males (11 out of 28 Males) were biofilm positive i.e. prevalence of biofilm positive female was higher as compared to male. The mean resistance percentage of male and female is $58.41 \%$ and $54.27 \%$ respectively towards antibiotics. This indicates that male are relatively more resistant than female (mean difference $=4.13 \%)(p=0.000)$. The mean sensitive percentage of male and female is $33.67 \%$ and $37.69 \%$ respectively, which indicates that female is relatively more sensitive than male (mean difference $=4.02 \%)(p=000)$. Sinha et al. justify it as male gender is a significant risk factor in acquiring UTI with antibiotic resistant strains. 33

Chloramphenicol (83\%), Amikacin (79\%), Imipenem (70\%) and Tobramycin (69\%) were found to be more sensitive, while most resistant were Ampicillin (100\%), Ceftazidime (100\%), Erythromycin (97\%), and Nalidixic Acid (85\%). Ceftazidime used usually to treat gram negative infections which are predominant in UTIs but it is found completely resistant in our study and is justified by $\mathrm{Du}$ et al., is due to simultaneous expression of ESBLs, the OprM efflux system, and AmpCover production. ${ }^{34}$ Daza et al. Shows that the antimicrobial agents with highest levels of activity against Gram-negative bacilli were amikacin, cefexime and imipenem, all of which are restricted to hospital use. ${ }^{35}$ This study significantly indicates that biofilm positive uropathogens are relatively more resistant than biofilm negative uropathogens which can also conclude that biofilm producing properties of bacteria makes them more resistance towards antibiotics. Relatively, decrease in the inhibition zone of biofilm producing bacteria in comparison to non-biofilm producers indicates the flow of bacteria towards resistance development.

Biofilm positive bacteria were found to be more resistant compared to biofilm negative bacteria i.e. TOB, CTR, COT, NIT, NX, CIP, AK, IPM, AZM and $\mathrm{C}$ were $29 \%, 27 \%, 25 \%, 17 \%, 16 \%, 15 \%, 9 \%$, $7 \%, 5 \%$ and $2 \%$ more resistant in biofilm positive bacteria compared to biofilm negative bacteria respectively. However, AMP and CAZ were 100\% resistant in both cases, whereas AZM and E were $2 \%$ more resistant in biofilm negative bacteria than biofilm positive bacteria. Similarly, biofilm negative bacteria were more sensitive as compared to biofilm positive bacteria where TOB, CTR, COT, AK, NIT, NX, CIP, C, NA, AZM and IPM were $33 \%, 20 \%, 19 \%, 18 \%, 13 \%, 11 \%, 6 \%, 5 \%$, $5 \%, 3 \%$ and $2 \%$ more sensitive than biofilm positive bacteria respectively. .

\section{CONCLUSIONS}

The prevalence rate of multidrug resistance in bacterial uropathogens is higher in biofilm producers as compared to non-biofilm producers. Biofilm forming characteristics of bacteria make them more resistant to antibiotics that lead to new challenges in the current antibiotics era.

It is important to find more effective method for diagnosing and quantifying biofilm infection and also development of more specific antimicrobial agents that would help to fight against biofilm formation. Limitations of this study are that hospital patient are only included and molecular level identification of biofilm is not performed. 


\section{ACKNOWLEDGEMENTS}

The authors are thankful to the entire team of Department of Microbiology, School of Health and
Allied Sciences, Pokhara University, Nepal as well as to the staff of Department of Microbiology, Western Regional Hospital and Western Regional Laboratory, Pokhara, Nepal.

To cite this article: Bhatta MP, Sapkota A, Subedi P, Chhetri SB, Pant DR, Pandit S et al. Biofilm formation by uropathogens and their susceptibility towards antimicrobial therapy. MJSBH. 2019;18(1): $13-22$.

Conflict of Interest: None declared

\section{REFERENCES}

1. Korbel L, Howell M, Spencer JD. The clinical diagnosis and management of urinary tract infections in children and adolescents. Paediatr Int Child Health. 2017;5:1-7.

DOI: https://doi.org/10.1080/20469047.2017.1382046

2. Abdallah NMA, Elsayed SB, Mostafa MMY, El-gohary GM. Biofilm forming bacteria isolated from urinary tract infection, relation to catheterisation and susceptibility to antibiotics. Int J Biotechnol Mol Biol Res. 2011;2:172-8.

3. Leitner L, Sybesma W, Chanishvili N, Goderdzishvili M, Chkhotua A, Ujmajuridze A et.al. Bacteriophages for treating urinary tract infections in patients undergoing transurethral resection of the prostate: a randomized, placebo-controlled, double-blind clinical trial. BMC. 2017;17:90.

DOI: https://doi.org/10.1186/s12894-017-0283-6

4. Kim B, Pai H, Choi WS, Kim Y, Kweon KT, Kim HA. Current status of indwelling urinary catheter utilisation and catheter-associated urinary tract infection throughout hospital wards in Korea: A multicenter prospective observational study. PLoS One. 2017;12:e0185369.

DOI: https://doi.org/10.1371/journal.pone.0185369

5. Mittal R, Aggarwal S, Sharma S, Chhibber S, Harjai K. Urinary tract infections caused by Pseudomonas aeruginosa: A Minireview. J Infect Public Health. 2009;2:101-11.

DOI: https://doi.org/10.1016/j.jiph.2009.08.003

6. Llor C, Bjerrum L. Antimicrobial resistance: risk associated with antibiotic overuse and initiatives to reduce the problem. Therapeutic Advances in Drug Safety. 2014;5(6):229-41.

7. Nadell CD, Xavier JB, Foster KR. The sociobiology of biofilms. FEMS Microbiol Rev. 2009;33:206-24. DOI: https://doi.org/10.1111/j.1574-6976.2008.00150.x

8. Palmer J, Flint S, Brooks J. Bacterial cell attachment, the beginning of a biofilm. J Ind Microbiol Biotechnol. 2007;34(9):577-88.

DOI: $10.1007 / \mathrm{s} 10295-007-0234-4$

9. Vu B, Chen M, Crawford RJ, Ivanova EP. Bacterial extracellular polysaccharides involved in biofilm formation. Molecules. 2009;14(7):2535-54.

DOI: $10.3390 /$ molecules 14072535

10. Flemming H-C, Neu TR, Wozniak DJ. The EPS Matrix: The "House of Biofilm Cells". Journal of Bacteriology. 2007;189(22):7945-7.

DOI: $10.1128 / \mathrm{JB} .00858-07$

11. Fallah F, Yousefi M, Pourmand MR, Hashemi A, Nazari A, Afshar D. Phenotypic and genotypic study of biofilm formation in Enterococci isolated from urinary tract infections. Microb Pathog. 2017;108:85-90. 
12. Saini H, Chhibber S, Harjai K. Azithromycin and ciprofloxacin: a possible synergistic combination against Pseudomonas aeruginosa biofilm-associated urinary tract infections. Int $\mathrm{J}$ Antimicrob Agents. 2015;45:359-67.

DOI: https://doi.org/10.1016/j.ijantimicag.2014.11.008

13. Schroeder M, Brooks BD, Brooks AE. The complex relationship between virulence and antibiotic resistance. Genes (Basel). 2017;8(1).

DOI: https://doi.org/10.3390/genes8010039

14. Danhorn T, Fuqua C. Biofilm formation by plant-associated bacteria. Annu Rev Microbiol. 2007;61:401-22.

DOI: https://doi.org/10.1146/annurev.micro.61.080706.093316

15. Busscher HJ, Stokoos I, JM S. Two-dimensional spatial arrangement of fibronectin adsorbed to biomaterials with different wettabilities. Cells Mater. 1991;1:49-57.

DOI: https://doi.org/10.1163/156856292X00097

16. Stewart PS, Costerton JW. Antibiotic resistance of bacteria in biofilms. The lancet. 2001;358:135-8. DOI: https://doi.org/10.1016/S0140-6736(01)05321-1

17. Stickler DJ. Bacterial biofilms in patients with indwelling urinary catheters. Nat Clin Pract Urol. 2008;5:598-608.

DOI: https://doi.org/10.1038/ncpuro1231

18. Freeman D, Falkiner F, Keane C. New method for detecting slime production by coagulase negative staphylococci. J Clin Pathol. 1989;42:872-4.

DOI: https://doi.org/10.1136/jcp.42.8.872

19. Hassan A, Usman J, Kaleem F, Omair M, Khalid A, Iqbal M. Evaluation of different detection methods of biofilm formation in the clinical isolates. Braz J Infect Dis. 2011;15:305-11.

DOI: https://doi.org/10.1590/S1413-867020110004000020

20. Jenkinson HF, LJ D. Interactions between Candida Species and Bacteria in Mixed Infections. In Brogden KA and Guthmiller JM (eds), Polymicrobinfect dis. 2001;357-73.

DOI: https://doi.org/10.1128/9781555817947.ch18

21. Biemer JJ. Antimicrobial susceptibility testing by the Kirby-Bauer disc diffusion method. Ann Clin Lab Sci. 1993;3:135-40.

22. Minardi D, d'Anzeo G, Cantoro D, Conti A, Muzzonigro G. Urinary tract infections in women: etiology and treatment options. Int J Gen Med. 2011;4:333-43.

DOI: $10.2147 /$ IJGM.S11767

23. Beyene G, Tsegaye W. Bacterial uropathogens in urinary tract infection and antibiotic susceptibility pattern in jimma university specialised hospital, southwest ethiopia. Ethiop J Health Sci. 2011;21:141-6. DOI: https://doi.org/10.4314/ejhs.v21i2.69055

24. John MS, Meenakshi K, Munilakshmi P, Reddy PS. Prevalence and Distribution of Bacterial Pathogens Causing Urinary Tract Infections in Humans: A Study from Tertiary Care Hospital in AP, India. Int J Curr Microbiol Appl. 2015;4:251-7.

25. Thapa P, Parajuli K, Poudel A, Thapa A, Manandhar B, Laudari D, et al. Causative Agents and Susceptibility of Antimicrobials among Suspected Females with Urinary Tract Infection in Tertiary Care Hospitals of Western Nepal. J Chitwan Med Coll. 2013;3:16-9.

DOI: https://doi.org/10.3126/jcmc.v3i2.8436

26. Baral P, Neupane S, Marasini BP, Ghimire KR, Lekhak B, Shrestha B. High prevalence of multidrug resistance in bacterial uropathogens from Kathmandu, Nepal. BMC. 2012;5:38.

DOI: https://doi.org/10.1186/1756-0500-5-38 
27. Subramanian P, Shanmugam N, Sivaraman U, Kumar S, Selvaraj S. Antiobiotic resistance pattern of biofilm-forming uropathogens isolated from catheterised patients in Pondicherry, India. Australas Med J. 2012;5:344-8.

DOI: https://doi.org/10.4066/AMJ.2012.1193

28. Al-Asoufi A, Khlaifat A, Tarawneh AI, Alsharafa K, Al-Limoun M , Khleifat K. Bacterial Quality of Urinary Tract Infections in Diabetic and Non Diabetics of the Population of Ma'an Province, Jordan. Pak J Biol Sci. 2017;20:179-88.

DOI: https://doi.org/10.3923/pjbs.2017.179.188

29. Mishra SK, Basukala P, Basukala O, Parajuli K, Pokhrel BM , Rijal BP. Detection of Biofilm Production and Antibiotic Resistance Pattern in Clinical Isolates from Indwelling Medical Devices. Curr Microbiol. 2015;1-70(1):128-34.

DOI: https://doi.org/10.1007/s00284-014-0694-5

30. Panda PS, Chaudhary U, Dube SK. Comparison of four different methods for detection of biofilm formation by uropathogens. Indian J pathol Microbiol. 2016;59:177-9.

DOI: https://doi.org/10.4103/0377-4929.182013

31. Niveditha S, Pramodhini S, Umadevi S, Kumar S, Stephen S. The Isolation and the Biofilm Formation of Uropathogens in the Patients with Catheter Associated Urinary Tract Infections (UTIs). J Clin Diagn Res: JCDR. 2012;6:1478-82.

DOI: https://doi.org/10.7860/JCDR/2012/4367.2537

32. Bellifa S, Hassaine H, Terki IK, Didi W, M'hamedi I, Lachachi M, et al. Study of Biofilm Production and Antimicrobial Resistance Pattern of Klebsiella Pneumoniae Isolated from Urinary Catheter at the University Hospital of Tlemcen. Am J Microbiol Biotech. 2016;3:13-7

33. Anoop S, Benny PV, Saritha SV, Arun H. Gender and antibiotic resistance pattern of uropathogen in a tertiary care level. Int J of Preventive and Therapeutic Med. 2013;1:5-8.

34. Du S, Kuo H, Cheng C, Fei A, Wei H, Chang S. Molecular mechanisms of ceftazidime resistance in Pseudomonas aeruginosa isolates from canine and human infections. Vet Med. 2010;55(4):172-82.

DOI: https://doi.org/10.17221/64/2010-VETMED

35. Daza R, Gutiérrez J, Piédrola G. Antibiotic susceptibility of bacterial strains isolated from patients with community-acquired urinary tract infections. Int J Antimicrob Agents. 2001;18:211-5.

DOI: https://doi.org/10.1016/S0924-8579(01)00389-2 